\title{
Features of the Implementation of Learning Based on Modular Technology in the Corporate Training Center
}

\author{
https://doi.org/10.3991/ijep.v11i2.18845 \\ Lyubov Plaksina $\left.{ }^{(}\right)$, Anton Lyzhin, Boris Guzanov, \\ Vyacheslav Tumakov, Alyona Glukhikh \\ Russian State Vocational Pedagogical University, Yekaterinburg, Russia \\ plt2006eyandex.ru
}

\begin{abstract}
Modular training technologies are one of the most relevant methods in the field of professional engineering corporate training. The research aims to identify and substantiate the organizational and pedagogical conditions for the effective implementation of modular technology for the development of professional competencies in welder students in a corporate training center. According to the results of the test of practical and theoretical knowledge, the experimental group showed statistically significantly higher results according to the learning results. The practical analysis of student achievements based on the proposed modular training system with the participation of two groups of male students undergoing vocational training (22 students in each group) showed that the experimental group provided more qualitative average answers to 9 out of 20 test questions, and the total average score was higher in this group. The experimental group also showed statistically significant and higher average scores in 5 practical tests. The average assessment of the experimental group ranged from 4.56 to 3.92, and the control group 3.66 to 2.88 (on a 5-point scale). The results of the study can be put into practice to improve the quality of engineering training in corporate training centers.
\end{abstract}

Keywords-Vocational education, dual education system, modular technology, personalization of learning

\section{Introduction}

Modern socio-economic conditions pose completely new challenges for industrial enterprises related to the adaptation of new technologies. Enterprise competitiveness is directly associated with the modernization of production facilities, which results in the emergence of new skills and job functions, as well as new competencies and professions; in turn, this necessitates training and retraining of personnel that take place in the context of a close cooperation between educational institutions and enterprises [1-3]. The relevance of the creation and development of the system is due to globalization, the rapid technical and technological re-equipment of the industry, the emergence of new jobs, and an increase in professional mobility, which creates the need for a new approach to training and retraining of personnel of industrial enterprises $[4$, 5]. 
A corporate training center implements the interaction between science, education and business to create an in-house training system that supports the ideology and strategy of enterprise development, and involves all major categories of personnel [4, $6]$. These centers are commonly found in technologically advanced countries such as Germany and the United States [6, 7]. An example is the Educational Center of the Chelyabinsk Pipe Rolling Plant Group (Chelpipe Group), the town of Pervouralsk, created in 2011 as part of a joint project of the Chelpipe Group, the government of the Sverdlovsk region and Pervouralsk Metallurgical College (PMC) to train metallurgists; the project was named Future of white metallurgy. In 2005, the Ministry of education of the Sverdlovsk region assigned the Educational Center of the Chelpipe Group the status of the Specialized Competence Center (SCC) of the WorldSkills Russia (WSR); thus, it became a training center focused on the improvement of professional skills to further participate in competitions. The major tasks of the WSR specialized competence center are to organize the preparation of teams for the participation in competitions in accordance with international standards, as well as to create an expert community involving teachers and masters of vocational training and prepare them in accordance with the WorldSkills requirements.

The relevance of the study is due to the new requirements for substantive and technological training within the framework of engineering and technical training for the development of an enterprise in accordance with the Future Skills initiative of the WorldSkills Russia Union in a corporate training center [1]. To increase the efficiency of practice-oriented corporate training, it was decided to implement a dual education system; according to it, $40 \%$ of the instructional time is devoted to theory and $60 \%$ to practice. This scheme is common in the corporate training market $[8,9]$.

The effectiveness of traditional pedagogical technologies is rather limited for the implementation of training and retraining of personnel involved in high-tech production. New learning solutions are being introduced to resolve the objective contradictions between education and professional activities [10], between rapidly changing needs for education and the rigid fixity of the content and structure of traditional educational programs; between the need to shift the focus of the content of education to the personal qualities of the student and the limited capabilities of traditional learning technologies $[11,12]$. Personalized learning with due regard to technological capabilities is one of the possible solutions to this problem [13, 14]. Module-based learning has great potential for solving contradictions in practice-oriented corporate training that takes place on the basis of the dual education system [15].

At the same time, in the pedagogic theory [16] and practice-oriented publications [6], there are no developed conditions for the effective application of modular technologies in corporate training, in particular, welder training. Thus, the research aims to identify and substantiate the organizational and pedagogical conditions for the effective implementation of modular technology for the development of professional competencies in welder students in a corporate training center [17].

The purpose of the study is to identify and substantiate the organizational and pedagogical conditions for the effective implementation of modular technology for the development of professional competencies in welder students in a corporate training center. 
The research hypothesis is that module-based learning implemented in corporate training can be an effective tool for the development of professional competencies in the context of future professional activities.

The structure of this article is as follows. Section 2 describes the review of the literature on corporate modular engineering education and the characteristics of its effectiveness. Section 3 contains a description of the methods used to create a modular methodology and to conduct experimental research. Section 4 analyses the results and achievements of the study, which provides evidence of the effectiveness of modular training on the basis of the results of pedagogical experience. Section 5 contains a discussion of the research and related findings.

\section{$2 \quad$ Literature Review}

More complex goals and objectives of education determined by modern development trends necessitate the further improvement of vocational training based on strengthening the interaction of all its components with production [18]. From this perspective, as noted by a number of researchers, module-based learning implemented in corporate education can be an effective tool for the development of professional competencies in the context of future professional activities when it meets the requirements of the training system used in the corporate training center [19].

Module-based learning is theoretically substantiated and described in [20, 21]. The UNESCO conference held in Paris in 1989 [22] gave the impetus for the introduction of modular technologies; it recommended the creation of open and flexible structures of education and vocational training allowing the adaptation to the changing needs of production, science, and local conditions. These requirements were best met by module-based learning, which made it possible to flexibly structure educational content by units, integrate various types and forms of education, choose the most suitable ones for a specific audience of students, who, in turn, received an opportunity to independently work with the individual curriculum at their own pace [23]. Currently, modular technologies are being actively implemented in the education systems of countries such as the United States, Great Britain, Holland, Germany, etc. [9].

No common approach to module-based learning has been elaborated so far [24]. Many researchers agree that learning based on modular technologies is the arrangement of the educational content of a specific program into complete modules that can be studied independently. At the same time, the material that does not contribute to the development of a skill for this type of activity should be excluded. The possibility of developing individual training programs based on modular ones is also being discussed $[6,20]$.

In the research by Yucevičienè, modular technology is described as the organization of independent work of students with individual programs. In the works by Russian researchers, the subject-subject relationship between the teacher and the student is traced, where both of them are the subject of the educational process.

When analyzing the process of designing and implementing module-based learning training, Yucevičienè [16] notes its systemic nature. Dewi and Primayana [15] believe 
that module-based learning is a specifically organized learning environment and define it as a sequential step-by-step process aimed at developing professional competencies. There is no doubt that such a step-by-step process requires didactic units that would include the necessary amount of educational information for mastering a particular skill $[3,17]$. These didactic units are called "training elements" [6].

One of the key concepts in module-based learning is the concept of a module. There is no clear and unambiguous definition to the concept. A module is defined as follows: a curriculum including a set of disciplines; a set of logically related topics in a specific training program; a tool to measure a certain unit of knowledge [13]; an independent complete part of the educational content of a training program [8-10].

The analysis of the works of Russian and foreign scientists allows us to identify the key directions of the theoretical analysis of the concept of a module. The analysis of the concept of a module is described in the works by Yucevičiene [16]. A module is defined as a specially designed educational package that includes a specific topic of the educational material, a task-oriented unit, and methodological support for achieving goals. In the study by Jalil et al. [18], a module is described as an autonomous part of the educational process, which includes educational goals, selected content for their achievement, developed means and methods for monitoring the digestion of didactic units.

The systemic analysis of the concept of a module is conducted in [15, 25]. Based on the systemic approach, the study defines a module as an operation in the general system of professional activity that covers one logical topic. In this case, a distinctive feature of the module is its autonomy and independence to achieve the pedagogical goals. The structure of the module is based on the specific job functions, which allows us to note the development of skills that are required to perform specific tasks; this will reduce the training period, which, in turn, will solve one of the key issues related to training competitive specialists and reducing the period of studies.

In our study, we are discussing the comprehensive development of a system of professional competencies and skills in students; thereby, the research relies on the systemic approach as the key approach to the development of the module structure. Within the framework of the approach, module-based learning involves modules. Each module, in turn, is a part of the professional activity (an operation). A module consists of actions, the sequence of which will lead to the acquisition of the necessary skill when performing the operation. Each action in an operation ensures the implementation of a certain skill, and the skills, in turn, are decomposed into minimal didactic units (training elements).

This definition of the module concept is fully consistent with learning based on the concept of the occupational skills module. An occupational skills module is a part of the activity related to the performance of job functions with clearly defined deadlines; a training element is a textbook that is usually a small book containing the necessary minimum of theoretical and practical information to acquire knowledge and skills [6].

The unique feature of the concept of the occupational skills module is the design of individual training programs based on modules in modern conditions, which becomes necessary for the training of workers at large industrial enterprises. Thus, a training program framework consists of several documents: job description; contents and 
description of modules; module analysis chart; a chart to select occupational skills; methodological support for the educational process; a set of training elements; drawings, various types of control; organizational documentation; description of student jobs; an academic progress report.

The approaches to the design of the documentation are also controversial [2]. Within the concept of the occupational skills model, which implies the creation of a documentation package, a systemic and activity approach has been implemented, which is the most efficient for the development of technologically advanced modular programs.

In accordance with the concept requirements, a modular program is composed of separate autonomous professional modules determined by the requirements of the enterprise. A module within the concept of the occupational skills model is a structural didactic unit of professional activity that has a definite beginning and end [7, 9, 26].

The literature review shows that modular technology is not always defined as a concept of the occupational skills model in corporate training centers [4]. For example, the Educational Center of the Chelyabinsk Pipe Rolling Plant Group considers modular technology (the concept of the occupational skills model) as a component of its dual education system that is focused on the result important for the employer, which is the ability to perform a specific type of professional activity; in accordance with this, the selection of the educational content of a flexible modular training program consisting of modules adequate to the selected operations is made [27]. The distinctive characteristics of module-based learning in corporate training centers are as follows: modular technologies provide a flexible choice of the methodology adapted to fit the needs of the group; there is a possibility to take corrective action to help some students reach the baseline level; there is a possibility to create an individual trajectory of each student development [28]; the risk of the subjective assessment of student performance is reduced; the modules can be combined to solve a task; and, finally, one of the most important advantages of modular technologies is the acceleration of the educational process and the cyclicity of passing control points in case of an unsatisfactory result. In addition, students note a small amount of "useless information" and a practice-oriented approach [29].

\section{$3 \quad$ Materials and Methods}

\subsection{Research methods}

The research is based on the theoretical and methodological analysis of scientific literature and normative documents, which made it possible to create and substantiate the organizational and pedagogical conditions for training workers, as well as to develop organizational and reference models of modular technology to train welders within the dual education system implemented in a corporate training center; it also contributed to the design of a modular welder program and a set of training elements. At the second stage of the research, the effectiveness of the developed modular program was assessed by testing practical skills and theoretical knowledge. 


\subsection{Experimental research base}

The research base is the Educational Center of the Pervouralsk New Pipe Plant that is involved in a private-public partnership with Pervouralsk Metallurgical College (PMC). The modular technology was developed for the interdisciplinary course (IDC.02.01) of Techniques and technology of manual arc welding (surfacing, cutting) with coated electrodes. The pedagogical experiment involved a group of 22 male welder students (program 15.01.05.) The welder (manual and partly mechanized welding) training program is based on basic general education and practical training in the corporate training center of the Pervouralsk New Pipe Plant. A control group of 22 participants (all men) was formed. The control group was trained in accordance with the traditional program while the experimental one relied on modular technology. The questionnaire consisted of 20 theoretical questions; each question had 3 answer options (only 1 option was correct and counted). There were also 5 practical tasks related to engineering. The practical task was assessed by the teacher on the basis of current regulatory requirements for the quality of work on a 5-point scale (5 is the maximum point).

The average group score by each question and the standard deviation were calculated; then the results of the experimental and control groups were analyzed and compared.

For statistical processing of the results obtained during the survey, as well as for visualization of the results of statistical data processing, the software package was used MS Excel 2019.

The participation was voluntary and anonymous. No personal data were retained or used; the safety of personal data and their non-distribution were guaranteed. Participation in the experiment and the scores received did not affect further careers of the participants.

\section{$4 \quad$ Results}

In accordance with the first organizational and pedagogical condition for the effective development of professional competencies according to the research hypothesis, modular technology is structured as a component of the dual education system implemented in the training center.

The second organizational and pedagogical condition relates to the modular technology focus on the result that is important to the employer and observed in specific professional actions; thus, the selection of the educational content is based on the analysis of a specific type of activity of specialists, which is considered as a set of operations and actions performed. Therefore, the concept of the occupational skills model, which is based on the selection of the educational content in accordance with the analysis of the types of professional activities performed by the enterprise personnel, was chosen to design the modular welder training technology. From the perspective of the occupational skills model, the modular training program is flexible enough and focused on teaching to perform production operations integrally. 
The training program is a modular program with a flexible structure consisting of modules that are adequate to the content of the selected operations. Each module is structured into units focused on the development of competencies to perform the selected actions.

Within the framework of the study, pedagogical conditions are described as the circumstances of the educational process, which are the result of the purposeful selection, design, and application of the content elements, methods, techniques, and forms of education to achieve them.

Stage 3. Within the framework of the first pedagogical condition, a general model of the dual education system implemented in the Educational Center of the Pervouralsk New Pipe Plant was developed. The place of modular technology being discussed was determined in the model. The general model for the implementation of the dual education system in the Educational Center of the Pervouralsk New Pipe Plant has specific features. The educational process can be roughly divided into 2 parts: theoretical and practical. The theoretical part is implemented at the Pervouralsk Metallurgical College (PMC). The practical part includes laboratory classes and practical training sessions (conducted by the employees of the corporate training center), as well as practical activities that take place at the production facilities of the Pervouralsk New Pipe Plant under the guidance of the corporate training center.

The model of welder training in the context of the dual system of the corporate training center of the Pervouralsk New Pipe Plant is shown in Fig. 1.

The Professional training module is aimed at consolidating the disciplines from the modules above and the development of professional knowledge and skills in welders. The study of the module is completely managed by the Educational Center of the Pervouralsk New Pipe Plant. The module contains several professional modules (PM) aimed at the development of specific skills to perform specific types of activities: Professional module 1 "Weld preparation and quality control of welded seams after welding", Professional module 2 "Techniques and technology of manual arc welding (surfacing, cutting) with covered electrodes", Professional module 5 "Gas welding (surfacing)".

Each module consists of interdisciplinary courses, which, in turn, have a theoretical and practical part (Table 1). The theoretical part is implemented by the staff of the Pervouralsk Metallurgical College, laboratory and practical classes - by trainers and instructors of the corporate training center of the Pervouralsk New Pipe Plant. After mastering interdisciplinary courses, the knowledge and skills gained are consolidated through practical training conducted by the staff of the educational center. Next, knowledge and skills are solidified and put into practice at the production facilities of the Pervouralsk New Pipe Plant. The interdisciplinary course is aimed at developing professional competencies described in Table 2. 


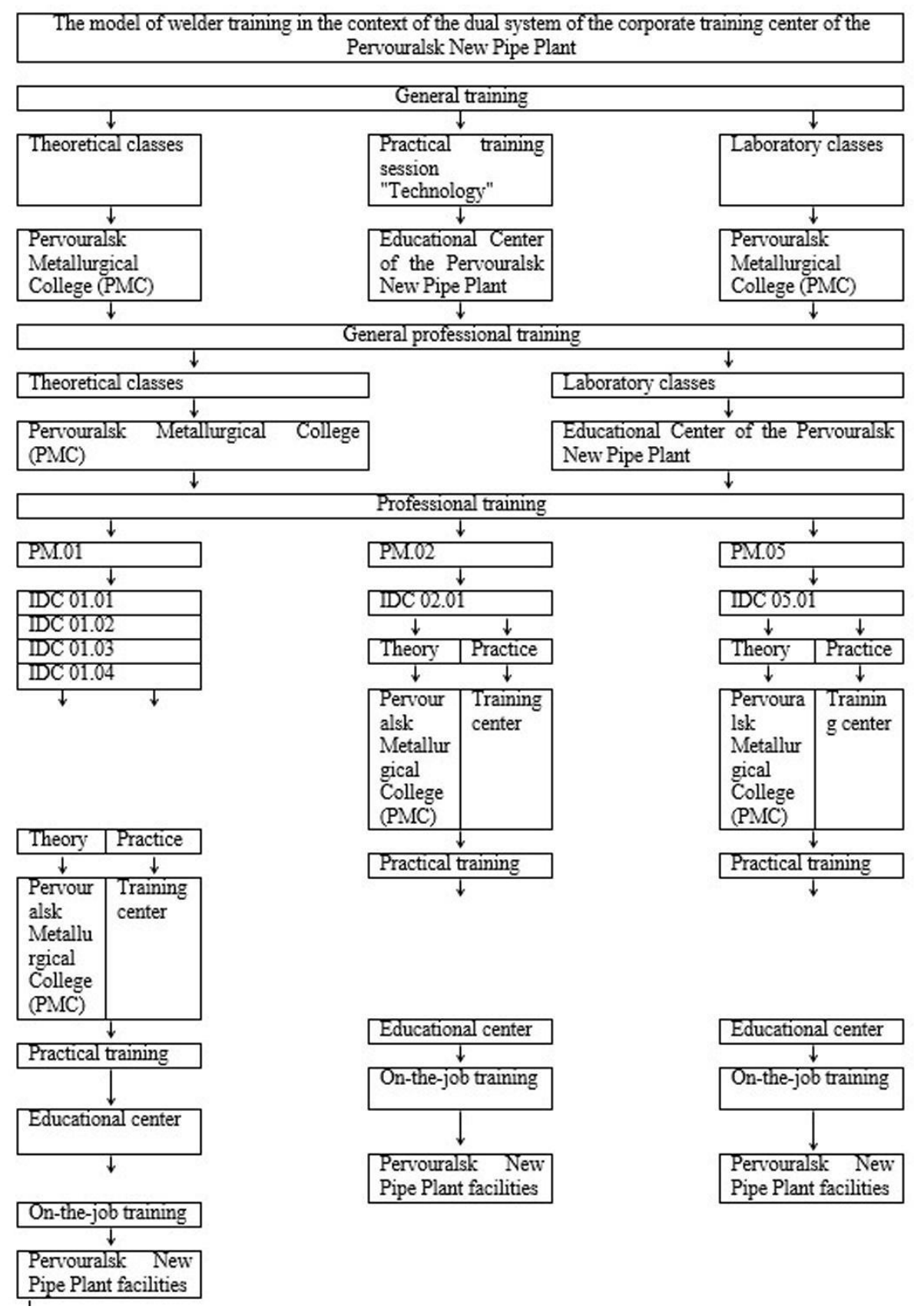

Fig. 1. The model of welder training in the context of the dual system of the corporate training center of the Pervouralsk New Pipe Plant 
Table 1. Professional modules and contained interdisciplinary courses

\begin{tabular}{|l|l|l|l|l|}
\hline Professional modules & \multicolumn{4}{|c|}{ Contained interdisciplinary courses } \\
\hline $\begin{array}{l}\text { "Weld preparation and control of } \\
\text { welded seams after } \\
\text { welding" }\end{array}$ & $\begin{array}{l}\text { IDC.01.01 } \\
\text { "Fundamentals } \\
\text { of welding } \\
\text { technology } \\
\text { and welding } \\
\text { equipment" }\end{array}$ & $\begin{array}{l}\text { IDC.01.02 } \\
\text { "Technology of } \\
\text { production of } \\
\text { welded struc- } \\
\text { tures" }\end{array}$ & $\begin{array}{l}\text { IDC.01.03 } \\
\text { "Preparatory and } \\
\text { assembly opera- } \\
\text { tions before } \\
\text { welding" }\end{array}$ & $\begin{array}{l}\text { IDC.01.04 } \\
\text { "Quality control } \\
\text { of welding joints }\end{array}$ \\
\hline $\begin{array}{l}\text { "Techniques and } \\
\text { technology of manual } \\
\text { arc welding (surfacing, } \\
\text { cutting) with coated } \\
\text { electrodes" }\end{array}$ & $\begin{array}{l}\text { IDC.02.01 } \\
\text { "Techniques } \\
\text { and technolo- } \\
\text { gy of manual } \\
\text { arc welding } \\
\text { (surfacing, } \\
\text { cutting) with } \\
\text { coated elec- } \\
\text { trodes" }\end{array}$ & & & \\
\hline "Gas welding (surfac- \\
ing)" & $\begin{array}{l}\text { IDC.05.01 } \\
\text { "Techniques } \\
\text { and technolo- } \\
\text { gy of gas } \\
\text { welding } \\
\text { (surfacing)" }\end{array}$ & & & \\
& & & \\
& & & \\
\end{tabular}

Table 2. Professional competencies (IDC 02.01)

\begin{tabular}{|l|l|}
\hline \multicolumn{1}{|c|}{ Professional competency } & \multicolumn{1}{c|}{ Competency description } \\
\hline PC 2.1. & $\begin{array}{l}\text { Manual arc welding of various parts made of carbon and structural steel } \\
\text { in all spatial positions of the welding joint }\end{array}$ \\
\hline PC 2.2. & $\begin{array}{l}\text { Manual arc welding of various parts made of non-ferrous metals and } \\
\text { alloys in all spatial positions of the welding joint }\end{array}$ \\
\hline PC 2.3. & Manual arc welding of various parts with coated electrodes \\
\hline PC 2.4. & Arc cutting of various parts \\
\hline
\end{tabular}

The relevance of the development of the specified professional competencies is confirmed by the analysis of the welder qualification standard, which includes the job functions corresponding to the professional competencies.

In accordance with the second and third organizational and pedagogical conditions, the modular training program is designed based on the approach of the occupational skills module. The modular training program should include 2 operations: "Manual arc welding in the flat position" and "Manual arc welding in the vertical position".

Within the occupational skills module concept, a module is the description of an operation performed by the worker. The analysis of the operations performed by the welder when welding in the flat and vertical position shows that the actions prior to the welding process and afterwards are identical: "Safety in the welding area"; "Preparation of equipment, materials, and workplace for manual arc welding"; "Preparation of metal for manual arc welding"; "Maintaining the burning of the welding arc"; "Quality control of welding joints". The actions of a welder performing vertical or flat welding differ: "Manual arc welding in the flat position", "Manual arc welding in the vertical position". Therefore, a reference model of the modular training program according to IDC.02.01 - "Techniques and technology of manual arc welding (surfacing, cutting) with coated electrodes" corresponds to the structure shown in Fig. 2. 
The structure of the program based on the occupational skills model is built as follows: operations are selected from a certain area of work, which in turn are divided into actions (steps). Each step is subdivided into skills, skills - into a minimum didactic unit of a modular training program, a training element.

The implementation of a modular program requires the development of the content of training elements, which will be the methodological material for conducting classes. In accordance with the concept of the educational skills model, each training element consists of three banks: coordination, informational, and assessment.

The coordination bank contains training goals, a list of required equipment and materials. The goal is specific, clear and unambiguous.

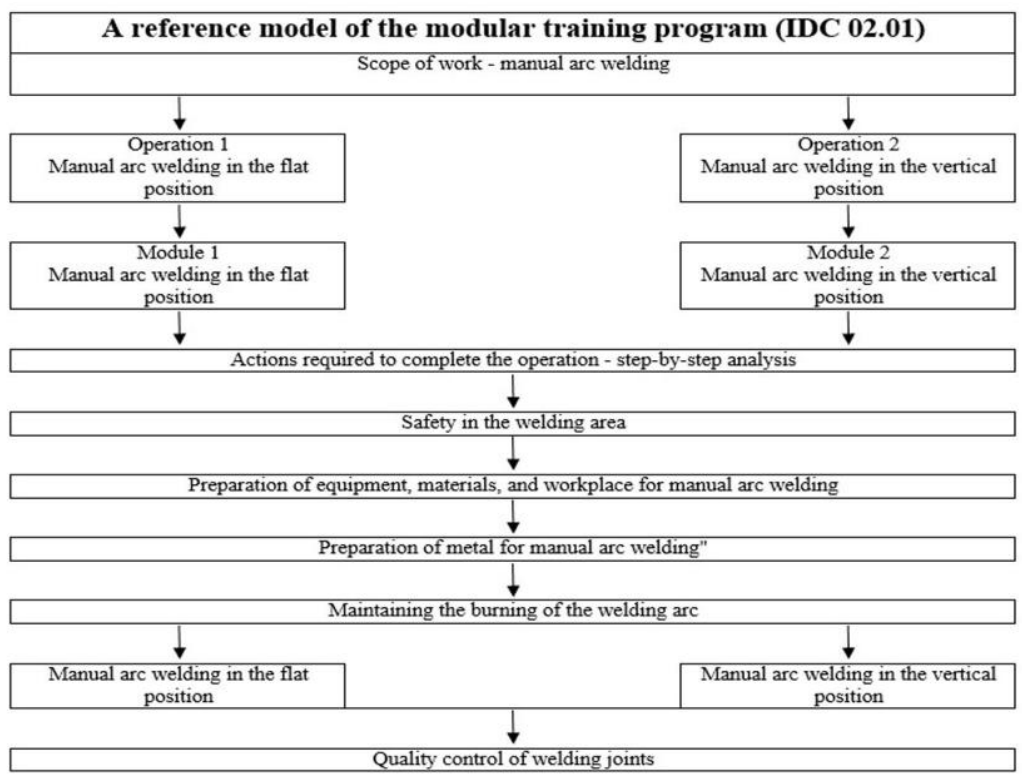

Fig. 2. A reference model of modular technology (IDC 02.01)

The information bank contains the educational material that makes up the biggest part of the training element. In most cases, the page is divided into two columns: the text is on the left and the process or result of an action is visualized on the right.

The assessment bank contains tasks and tests that allow assessing the development of a given didactic unit. After mastering all training elements of the module, a twostage intermediate assessment is carried out. Training elements of the categories of 01, 03, 04, 05, 06 are checked by testing (all tasks must be correctly solved), the elements of category 02 - by a practical task. 
Training elements are divided into categories:

- 01 - Labor protection

- 02 - Instructional, activity

- 03 - Theoretical

- 04 - Graphic information

- 05 - Methods

- 06 - Equipment

Categories 01, 03, 04, 05, and 06 are designed to develop basic knowledge while category 02 forms a practical skill. Therefore, all training elements, except 02 , contribute to the environment and conditions for conducting practical classes in the most efficient way. Based on the foregoing, we can conclude that the theoretical and practical content of a module of the program based on the occupational skills model fully reflects the dual education system adopted in the corporate training center as a basis.

Based on this approach to the design of training elements, a set of training elements of the categories of 01-06 consisting of 27 pieces was developed.

The objective verification of the results of the application of a modular training program based on the dual education system implemented in the corporate training center is presented in Fig. 3 and 4. Fig. 3 presents the results of the theoretical test.

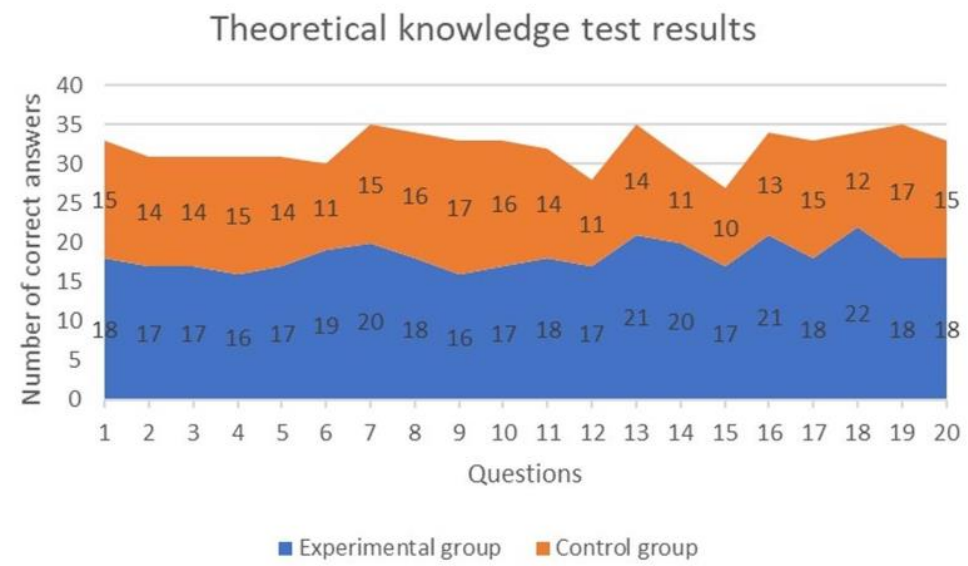

Fig. 3. Theoretical knowledge test results

The standard deviation of the experimental group results was about 1.71 while in the control one, it was 2.04 . The experimental group provided more qualitative average answers to 9 out of 20 test questions, and the total average score was higher in this group. Moreover, the average total number of correct answers in the experimental group was bigger than in the control one. Thus, it can be concluded that theoretical knowledge in the experimental group was mastered better.

Fig. 4 shows the results of the practical tasks. In all tasks, the experimental group performed better. The results of all five tests are statistically significant; the difference 
in the results does not fall within the total error. The only exception is test 3 , in which the total error limits of the two groups are as close as possible, but do not intersect with each other.

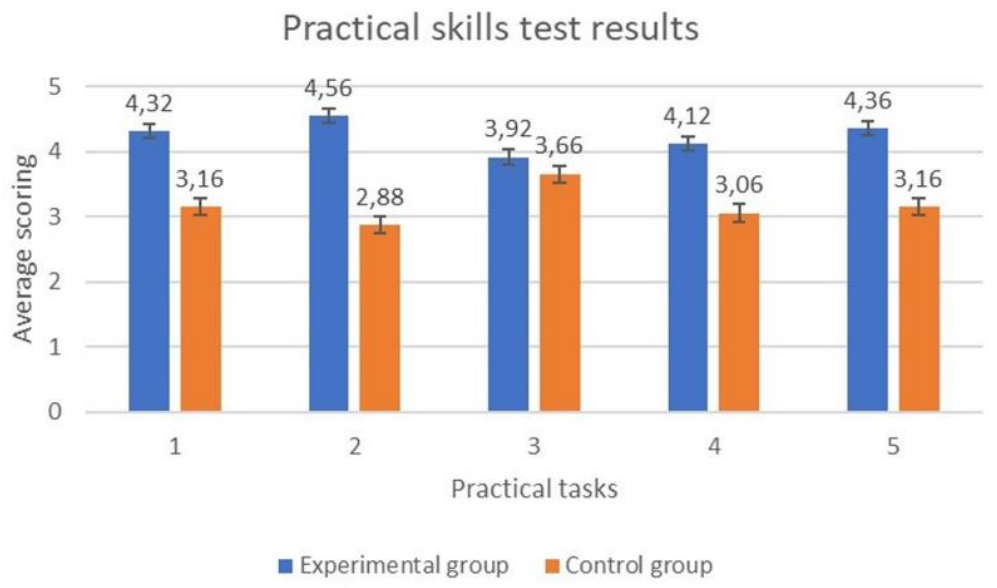

Fig. 4. Practical skills test results

Thus, the experimental group has mastered practical skills better compared to the control one. In general, this proves a higher efficiency of learning based on the modular system proposed in the study.

\section{Discussion}

The introduction of competence-oriented federal state educational and professional standards into training that are designed to reveal the functions of various jobs, including WorldSkills standards, reflects modern global trends in the formation and development of professional competencies of workers [1, 11]. Modern standards that determine the requirements for the training of workers from the perspective of its content establish the principles of selection and formation of the competence-oriented subject area of study. However, the choice of training technologies is often outside the framework of the standards. At the same time, in the competence-oriented training of workers, it is necessary to implement an activity approach to the structure and implementation of training and, consequently, the relevant technologies based on the activity approach. Modular technology is one such technologies [10].

No common approach to module-based learning has been elaborated so far. According to Thuneberg et al. [24] learning based on modular technologies is the arrangement of the educational content of a specific program into complete modules that can be studied independently. A number of researchers believe that modular technology is the organization of independent work of students with individual programs $[10,27]$. Module-based learning is a specifically organized learning environment and define it as a sequential step-by-step process aimed at developing profes- 
sional competencies. In the study by Jalil et al. [18], learning based on modular technology is described as an autonomous part of the educational process, which includes educational goals, selected content for their achievement, developed means and methods for monitoring the digestion of didactic units.

In a number of countries, in particular, in Germany, modular training programs are widely implemented as a basis for corporate training due to constant changes in engineering technologies used in the industry. The industry becomes the basis for training professionals; and the STEM methodology, dual education system and collaborative learning techniques are widely used for training [7, 9, 24].

Modular training programs based on various concepts have a different structure and are accompanied by different types of documents [30]; however, all of them include three basic components: a purposeful and meaningful training program, a bank of educational documentation, and a package of control materials. The program proposed in this study is organized in a similar way.

The approaches to the design of the documentation are also controversial. The advocates of the subject and activity approach, for example, the authors of [3] note that the design of educational documentation should be based on the system of didactic goals identified based on the analysis of future job functions. Modular training programs and training elements are created according to the goals set. The dual features of the learning objectives are contrasted with the contextual approach, which implies the choice of the educational content with a higher degree of the necessary material for the implementation of a given type of activity. The structure of the course is developed based on the type of activity [17,31].

In a number of studies within the concept of the occupational skills model, a systemic and activity approach has been implemented; it involves the creation of a documentation package and is the most efficient for the development of technologically advanced modular programs [6].

Thus, the approaches of various scientists to modular technology and its capabilities have been analysed [32]. There is no common approach to modular technology today [21, 28]; however, there are well-structured and well-proven concepts of learning based on modular technologies. The comparative analysis showed that the concept of the occupational skills model is characterized by the systemic and activity approach, the well-structured terminological apparatus, a clearly defined process of designing modular technologies, and a detailed study of the types of educational and program documentation $[33,34]$. There is a range of pedagogical technologies that can provide the proper level of training in a corporate training center; however, the concept of the occupational skills model, which can ensure the flexibility of the educational process and an increased quality of the development of professional competencies, meets the goals and requirements of the customer to the greatest extent [17].

\section{Conclusion}

The study confirmed the relevance of the problem of identifying and substantiating the organizational and pedagogical conditions for professional training in a corporate 
training center and the need to develop new approaches to the problem within the concept of the FutureSkills initiative by the WorldSkills Russia Union. The analysis of the approaches to the training of specialists in the context of modern enterprises has shown that a modular approach that allows taking into account the specifics of training in a modern enterprise and has a flexible structure of the content and organization of the training process is the most efficient for the development of professional competencies.

Based on the analysis of the works by Russian and foreign researchers, we chose an approach that describes learning based on modular technology as a set of successive actions for the design and implementation of a phased learning process that involves autonomous modules, the development of which guarantees the achievement of didactic goals. As a result of the study, it was established that the development of professional competencies of workers within the training center of the enterprise can be effective when a number of organizational and pedagogical conditions described in the work are met. Thus, an organizational model for training specialists within a corporate training center was proposed; a reference model of dual welder training was developed based on the use of modular technology in the context of corporate education; a modular training program was also developed; a set of training elements (27 pieces) was created. It should be noted that during the development of the modular training program, all documents required by the concept of the occupational skills model were drafted. The practical analysis of student achievements based on the proposed modular training system with the participation of two groups of men undergoing vocational training (22 students in each group) showed that the experimental group provided more qualitative average answers to 9 out of 20 test questions, and the total average score was higher in this group. The experimental group showed statistically significant and higher average scores in 5 practical tests. The results of the study can be put into practice to improve the quality of engineering training in corporate training centers. Future research work in the field of the problems of this work should cover the features of the application of the modular methodology, taking into account the gender differentiation of the subjects, and should also include deeper objective studies of the academic effectiveness of training and the effectiveness of the application of the methodology for other engineering and technical specialties.

Despite these extremely positive results, research is limited to only one specific technical specialty, while the use of modular technical engineering training can be extended to many specialties. Men also took part in the study, and the gender aspect of the effectiveness of the modular program of the type under consideration could not be considered.

\section{$7 \quad$ References}

[1] Fedorov V. A., Vasiliev S. V. (2014). Basic principles of model building for competitive workforce training at industrial enterprises. The Education and science journal, 6: 56-76. https://doi.org/10.17853/1994-5639-2014-6-56-76

[2] Liu, Y., Zhong, W. (2018). Education and Training Management Model and Incentive Mechanism based on Core Employees of Scientific and Technological Small and Micro 
Enterprises. Educational Sciences: Theory \& Practice, 18(6): 2699-2706. https://doi.org/10.12738/estp.2018.6.169

[3] Rüütmann, T. (2019). Engineering Pedagogy Science as the Contemporary Basis for Effective Teaching of Science, Technology and Engineering. Proceedings of the 3rd International Baltic Symposium on Science and Technology Education, BalticSTE2019, June 1720 2019, Siauliai, Lithuania.

[4] Mahon, K., Francisco, S., Kemmis, S. (2016). Exploring education and professional practice: Through the lens of practice architectures. Singapore: Springer.

[5] Hrmo, R., Miština, J., Krištofiaková, L. (2016). Improving the quality of technical and vocational education in Slovakia for European labour market needs. International Journal of Engineering Pedagogy (iJEP), 6(2): 14-22. https://doi.org/10.3991/ijep.v6i2.5369

[6] Michael, S., Artem, C. (2016). Current trends in personnel training in the United States industry. South Ural State University Bulletin. Series: Computer Technologies, Automatic Control, Radio Electronics, 16(4): 83-93.

[7] Von Maurice, J., Roßbach, H. G. (2017). The educational system in Germany. Structural Context of Refugee Integration in Canada and Germany, 15: 49-53.

[8] Remington, T. F. (2017). Business-government cooperation in VET: a Russian experiment with dual education. Post-Soviet Affairs, 33(4): 313-333. https://doi.org/10.1080 /1060586x.2017.1296730

[9] Yu, P. A. (2019). Germany's dual education system: the assessment by its subjects. Education and Science, 21(5): 130-156.

[10] Esteller, L. J., Molas, A., Boer, D., Krüger, K. (2019). Development of dual engineering programs in Cambodia, China, India and Russia. EDULEARN19 Proceedings 11th International Conference on Education and New Learning Technologies, Palma, Spain. https://doi.org/10.21125/edulearn.2019.0051

[11] Zeer, E. F., Bragina, I. (2016). Valuable and Professional Orientations as a Social and Psychological Resource of Development of a Modern Worker. International Journal of Environmental and Science Education, 11(15): 7791-7802.

[12] Zeer, E. F., Tretyakova, V. S., Miroshnichenko, V. I. (2019). Strategic Directions of Pedagogical Personnel Training for the System of Continuing Vocational Education. The Education and Science Journal, 21(6):93-121. https://doi.org/10.17853/1994-5639-2019-6-93$\underline{121}$

[13] Connolly, M., James, C., Fertig, M. (2019). The difference between educational management and educational leadership and the importance of educational responsibility. Educational Management Administration \& Leadership, 47(4): 504-519. https://doi.org/10.1177 $\underline{1741143217745880}$

[14] Ermakov, D. S., Kirillov, P. N., Koryakina, N. I, Yankevich, S. A. (2020). Personalized model of education with the use of a digital platform. Moscow: "Platform of a new school".

[15] Dewi, P. Y. A., Primayana, K. H. (2019). Effect of learning module with setting contextual teaching and learning to increase the understanding of concepts. International Journal of Education and Learning, 1(1): 19-26. https://doi.org/10.31763/ijele.v1i1.26

[16] Yucevičienè, P. A. (1989). Theory and practice of modular training. Kaunas: Sviesa.

[17] Schefer-Wenzl, S., \& Miladinovic, I. (2019). Developing Complex Problem-Solving Skills: An Engineering Perspective. International Journal of Advanced Corporate Learning (iJAC), 12(3), 82-88. https://doi.org/10.3991/ijac.v12i3.11067

[18] Jalil, J. M. N., Alvarez, E. R., García, I. R. K., Almaguer, S. P. (2020). Work in Progress: Design and Construction of Physics Laboratory Equipment and an Authentic Evaluation System as a Pedagogical Tool in the Integral Training of Engineering Students. 2020 IEEE 
Global Engineering Education Conference (EDUCON), Porto, Portugal. https://doi.org/10.1109/educon45650.2020.9125294

[19] Davydova N. N., Dorozhkin E. M., Fedorov V. A. (2018). Educational research networks principles of organization. International Journal of Engineering \& Technology, 7(2.13): 24-29. https://doi.org/10.14419/ijet.v7i2.13.11573

[20] Schmidt, D., Kirby, S. (2016). A modular approach to rural and remote research education: a project report. Rural and Remote Health, 16: 3609

[21] Nardo, M. T. B. (2017). Modular instruction enhances learner autonomy. American Journal of Educational Research, 5(10): 1024-1034

[22] Désiré P. (1989). The Modular approach in technical education. Paris: UNESCO.

[23] Schmidt, B. (2015). Students' perception of different learning options and use of authentic research papers in a first-year engineering course. International Journal of Engineering Pedagogy (iJEP), 5(4), 29-37. https://doi.org/10.3991/ijep.v5i4.4923

[24] Thuneberg, H. M., Salmi, H. S., Bogner, F. X. (2018). How creativity, autonomy and visual reasoning contribute to cognitive learning in a STEM hands-on inquiry-based math module. Thinking Skills and Creativity, 29: 153-160. https://doi.org/10.1016/j.tsc.2018.07.003

[25] Khabibah, E. N., Masykuri, M., Maridi, M. (2017). The effectiveness of module based on discovery learning to increase generic science skills. Journal of Education and Learning, 11(2): 146-153. https://doi.org/10.11591/edulearn.v11i2.6076

[26] The dual education system in Germany, Kazakhstan, Russia (2014). Accreditation in Education. Available at: http://www.akvobr.ru/opyt_dualnogo_obuchenia.html(accessed $15 \mathrm{Ju}$ ly 2020)

[27] Qadir, J., Yau, K. L. A., Imran, M. A., Al-Fuqaha, A. (2020). Engineering education, moving into 2020s: Essential competencies for effective 21st century electrical and computer engineers. EdArXiv, 28 April: 1-9. https://doi.org/10.35542/osf.io/gptse

[28] Yell, M. L. (2017). Individualization is special education: A response to Czapanskiy. Australia \& New Zealand Journal of Law \& Education, 46: 245

[29] Murati, R., Ceka, A. (2017). The use of technology in educational teaching. Journal of Education and Practice, 8(6): 197-199

[30] Goldshmid, B., Goldshmid, M. (1972). Modular Instruction in Higher Education. Higher Education, 2: 15-32

[31] Ercan, F., Sale, D., \& Kristian, N. (2016). Innovative curriculum to enhance the learning experience of electrical and mechanical engineering students. International Journal of Engineering Pedagogy (iJEP), 6(3), 37-44. https://doi.org/10.3991/ijep.v6i3.5765

[32] International Center for the Development of a Modular Learning System (2018). Available at: http://mtn-module.ru (accessed 15 July 2020)

[33] Andersson, C., \& Logofatu, D. (2017). A blended learning module in statistics for computer science and engineering students revisited. International Journal of Engineering Pedagogy (iJEP), 7(4), 66-77. https://doi.org/10.3991/ijep.v7i4.7441

[34] Amin, M., \& Kaprawi, N. (2019). Content Learning Indicator in Equivalence Checking between Skills Module and Academic Module for APEL Process. International Journal of Emerging Technologies in Learning (iJET), 14(20), 58-72. https://doi.org/10.3991 lijet.v14i20.11459 


\section{Authors}

Lyubov Plaksina is a Candidate of technical sciences, Associate Professor, Department of engineering and vocational training in mechanical engineering and metallurgy, Russian State Vocational Pedagogical University, Yekaterinburg, Russia.

Anton Lyzhin is a Candidate of pedagogical sciences, Vice-Rector for Science, Innovation Policy and External Relations, Russian State Vocational Pedagogical University, Yekaterinburg, Russia.

Boris Guzanov is a Doctor of technical sciences, Head of the Department of engineering and vocational training in mechanical engineering and metallurgy, Russian State Vocational Pedagogical University, Yekaterinburg, Russia.

Vyacheslav Tumakov is an undergraduate, Department of engineering and vocational training in mechanical engineering and metallurgy, Russian State Vocational Pedagogical University, Yekaterinburg, Russia.

Alyona Glukhikh is an undergraduate, Department of engineering and vocational training in mechanical engineering and metallurgy, Russian State Vocational Pedagogical University, Yekaterinburg, Russia.

Article submitted 2020-09-25. Resubmitted 2020-11-20. Final acceptance 2020-11-20. Final version published as submitted by the authors. 